\title{
SEPT9 Gene
}

National Cancer Institute

\section{Source}

National Cancer Institute. SEPT9 Gene. NCI Thesaurus. Code C97897.

This gene plays a role in actin filament dynamics. 